\title{
Assessment of anxiolytic potential and acute toxicity study of Combretum micranthum G. Don. leaves (Combretaceae)
}

\begin{tabular}{|c|c|}
\hline \multicolumn{2}{|c|}{$\begin{array}{l}\text { Authors: } \\
\text { Mohammed O. Amali } 10 \\
\text { Soliu A. Atunwa } 1 \\
\text { Quadri A. Omotesho } \\
\text { Eniola O. Oyedotun } \\
\text { Akeem I. Olapade }^{1}\end{array}$} \\
\hline \multicolumn{2}{|c|}{$\begin{array}{l}\text { Affiliations: } \\
{ }^{1} \text { Department of } \\
\text { Pharmacology and } \\
\text { Toxicology, Faculty of } \\
\text { Pharmaceutical Sciences, } \\
\text { University of Ilorin, llorin, } \\
\text { Nigeria }\end{array}$} \\
\hline \multicolumn{2}{|c|}{$\begin{array}{l}\text { Corresponding author: } \\
\text { Soliu Atunwa, } \\
\text { atunwa.sa@unilorin.edu.ng }\end{array}$} \\
\hline \multicolumn{2}{|c|}{$\begin{array}{l}\text { Dates: } \\
\text { Received: } 05 \text { June } 2020 \\
\text { Accepted: } 29 \text { Aug. } 2020 \\
\text { Published: } 18 \text { Dec. } 2020\end{array}$} \\
\hline \multicolumn{2}{|c|}{$\begin{array}{l}\text { How to cite this article: } \\
\text { Amali, M.O., Atunwa, S.A., } \\
\text { Omotesho, Q.A., } \\
\text { Oyedotun, E.O. \& Olapade, } \\
\text { A.I., 2020, 'Assessment of } \\
\text { anxiolytic potential and acute } \\
\text { toxicity study of Combretum } \\
\text { micranthum G. Don. leaves } \\
\text { (Combretaceae)', Journal of } \\
\text { Medicinal Plants for } \\
\text { Economic Development 4(1), } \\
\text { a97. https://doi.org/10.4102/ } \\
\text { jomped.v4i1.97 }\end{array}$} \\
\hline \multicolumn{2}{|c|}{$\begin{array}{l}\text { Copyright: } \\
\text { C 2020. The Authors. } \\
\text { Licensee: AOSIS. This v } \\
\text { is licensed under the } \\
\text { Creative Commons } \\
\text { Attribution License. }\end{array}$} \\
\hline \multicolumn{2}{|l|}{ Read online: } \\
\hline 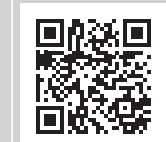 & $\begin{array}{l}\text { Scan this QR } \\
\text { code with your } \\
\text { smart phone or } \\
\text { mobile device } \\
\text { to read online. }\end{array}$ \\
\hline
\end{tabular}

Background: Combretum micranthum G. Don. (Combretaceae) is an ethnomedicinally valuable, undomesticated and indigenous shrub of West Africa. However, its anxiolytic potential have not been reported despite its ethanolic extract being used ethnomedicinally in the management of anxiety disorders.

Aim: To determine the acute toxicity effect and assess the behavioural effects and anxiolytic potential of C. micranthum G. Don. leaves in mice.

Settings: This study is an experimental design to evaluate the ethnomedicinal claim of Combretum micranthum G. Don using animal models of anxiety.

Methods: Fifty-six male and female mice, ranging in weight between $20 \mathrm{~g}$ and $30 \mathrm{~g}$ were randomly distributed into three main groups. The first group of mice $(n=6)$ was assigned for toxicity assessment $\left(\mathrm{LD}_{50}\right)$ study using the guideline of Organization for Economic Cooperation and Development (OECD). The second group of mice for behavioural study $(n=25)$ was further divided into five sub-groups. Sub-groups I, II and III were orally administered $500 \mathrm{mg} / \mathrm{kg}, 1000$ $\mathrm{mg} / \mathrm{kg}, 2000 \mathrm{mg} / \mathrm{kg}$ of ethanolic extract of C. micranthum (CmEE), respectively, whilst IV and V were intraperitoneally administered $1 \mathrm{mg} / \mathrm{kg}$ diazepam and normal saline $0.5 \mathrm{~mL}$, respectively. They were thereafter evaluated for novelty-induced behaviours: locomotion, rearing and grooming using Open Field Test (OFT). The third group of mice $(n=25)$ was treated similar to the pattern used in behavioural study and evaluated for anxiolytic activity of $C m E E$ using elevated plus maze (EPM) model. Data were expressed as mean \pm standard error of mean (S.E.M) and analysed using Student's- $t$ test, and one-way analysis of variance (ANOVA) followed by Student-Newman-Keuls (SNK) test with values of $p<0.05$ considered significant.

Results: The percentage yield of ethanolic leaf extract of C. micranthum was $14.28 \%$ weight/ weight $(\mathrm{w} / \mathrm{w})$. Combretum micranthum showed no toxicity when administered orally to mice $\left(\mathrm{LD}_{50} \geq 2000 \mathrm{mg} / \mathrm{kg}\right)$. Groups administered 500, 1000 and $2000 \mathrm{mg} / \mathrm{kg}$ of CmEE exhibited decreased locomotion $(p<0.05)$ when compared with saline group. There was significant decrease in rearing at $2000 \mathrm{mg} / \mathrm{kg}$ but increase in grooming in mice administered $2000 \mathrm{mg} / \mathrm{kg}$ of $C m E E$ was recorded. The groups administered 500, 1000 and $2000 \mathrm{mg} / \mathrm{kg}$ of $C m E E$ showed increased percentage time spent in the open arm in a dose-dependent pattern $(33.3 \%, 41.6 \%$ and $55.4 \%$, respectively) when compared with the saline group. There were significant dosedependent decreases in the indices of open arm avoidance at 1000 (48.9) and $2000 \mathrm{mg} / \mathrm{kg}$ (41.4) of $\mathrm{CmEE}$.

Conclusion: Combretum micranthum is non-toxic and preliminary data indicated that it possesses anxiolytic potential. However, it is recommended that further assays using other specific models of anxiety to determine its probable mechanism(s) of action should be explored.

Keywords: Combretum micranthum; Combretaceae; anxiety disorders; elevated plus maze; open field test; locomotion; rearing; grooming; index of open arm avoidance.

\section{Introduction}

Anxiety is a common psychiatric disorder which is usually associated with restlessness, difficulty in concentrating, nervousness, apprehension and panic (American Psychiatric Association 2000). The term 'anxiety disorder' refers to specific psychiatric disorders that involve extreme fear or worry and includes but not limited to generalised anxiety disorder (GAD), panic disorder and panic attacks, agoraphobia, social anxiety disorder, selective mutism, separation anxiety and social phobias (ADAA 2018; Rickels \& Schweizer 1997). Anxiety disorders are currently the most prevalent mental disorder (Bandelow \& Michaelis 2015). According to large population-based 
surveys, up to $33.7 \%$ of the population is affected by an anxiety disorder during their lifetimes (APA 2000; Bandelow \& Michaelis 2015; Martin 2003).

The symptoms associated with anxiety disorders could either be emotional or physical in nature (Shelton 2004; Yonkers et al. 2000). The emotional symptoms include feelings of apprehension or dread, trouble in concentrating, feeling tense and jumpy, irritability, restlessness amongst others (Billings 1986; Stein \& Stein 2008). On the other hand, the physical symptoms comprise pounding heart (Moser 2007), sweating, stomach upset or dizziness, frequent urination or diarrhoea, shortness of breath, tremors and twitches, muscle tension (Schweizer \& Rickels 1997), headaches, fatigue and insomnia, etc. (Koen \& Stein 2011; Vythilingam et al. 2000). Anxiety has been identified as the most common stress-related mood disorders causing disability and premature death (GBD 2015).

A large number of individuals suffering from anxiety disorders have access to conventional treatment (Bourin \& Thibaut 2013; Davidson 2001; Koen \& Stein 2011) yet symptoms usually persist (Bystritsky et al. 2013; Shelton 2004). This could be because of the several adverse effects of conventional drugs, which may have reduced patient compliance (Sheehan, Claycomb \& Kouretas 1980), hence the need to seek alternative therapies (Kunovac \& Stahl 1995). The use of natural products as complementary or alternative to conventional synthetic medicines in the treatment of many pathological conditions has increased substantially over the last decades (Kumar et al. 2012). This could be because of general perception of their safety and cultural acceptability, widespread availability, costeffectiveness, ease of administration, tolerability and general compliance (Calixto 2000; WHO 2005). Several studies have shown that various ethnomedicinal plants have been documented for the treatment of CNS disorders (Amali et al. 2019; Danmalam et al. 2017), which underscores the need for continuous research on potential medicinal plants that possess anxiolytic property.

Combretum micranthum (G. Don) (Figure 1) is an undomesticated shrub species of Western Africa that belongs to the family Combretaceae. It is commonly called

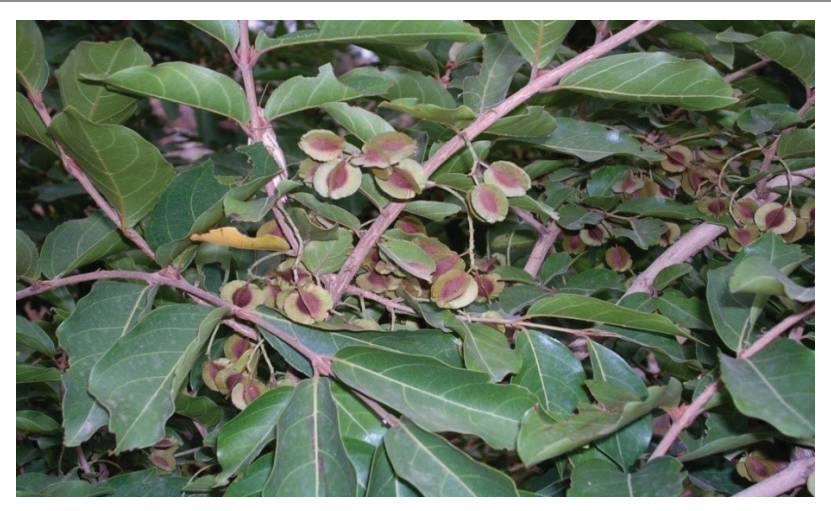

FIGURE 1: A picture of Combretum micranthum plant (G. Don). 'kinkileba' and is one of the most popular traditional bush teas of Senegal. It is also indigenous to Mauritania, Nigeria and Niger (Burkill 1985). Its local names are ògàn bule (Yoruba) and farar geézaà (Hausa). The plant is gathered from the wild by local people, mainly for medicinal use and to make a popular local tea called 'tisane de longue vie' or 'Seh-haw Kinkeliba' or 'quinquelibas drink', a refreshing tea traded as 'kinkéliba', which in English signifies 'infusion of long life' (Udoh et al. 2012).

The herbal beverage is commonly used to promote weight loss, digestion (Abdullahi et al. 2014), diuresis and as a mild antibiotic (Taura, Arzai \& Oyeyi 2009) to the urinary tract (Coulidiati et al. 2011; Fern 2014). The leaf extract of C. micranthum has been shown to possess analgesic, antiinflammatory (Eloff et al. 2008), antidiabetic (Chika \& Bello 2010), antibacterial (Abdel Kader et al. 2020; Jared et al. 2018), anti-hypertensive properties (Abdullahi et al. 2014; Arumugam et al. 2013) and it also prevents nosocomial infection (Udoh et al. 2012). Leaf extracts have been found to exhibit anti-viral properties (Bisso et al. 2015; Eloff et al. 2008; Tshikalange et al. 2008). The roots are diuretic, vermifuge and are used in the treatment of infertility, fevers, sores and veneral diseases (Ferrea et al. 1993; Masoko et al. 2010). The decoction of the leaves is used to treat black fever, hepatic diseases and various disorders of the respiratory system in Senegal, Mali and Burkina Faso (Gill 1992; Udoh et al. 2012). More so, the plant is commonly used in Burkina Faso and Cote d'Ivoire by native healers in the treatment of malaria (Fern 2014) and diarrhoea in Niger, West Africa (Manzo, Moussa \& Ikhiri 2017).

Further studies have shown that the ethanolic leaf extract of C. micranthum ( $\mathrm{CmEE}$ ) has CNS (antidepressant) activity (Danmalam et al. 2011) whilst it is also being used traditionally to treat anxiety disorders (oral communication). It is also a component of herbal mixture used in the traditional management of epilepsy by the Hausas of north-western Nigeria (Danmalam et al. 2017). In addition, recent studies have shown that the herb confers protective effects on central nervous system against environmental toxicants (Mohammed et al. 2020) and urinary system (Abdel Kader et al. 2020; Kpemissi et al. 2010). However, no report of its anxiolytic activity has been documented. Hence, this study was therefore designed to determine the acute toxicity and evaluate the behavioural effects and anxiolytic potential of the $\mathrm{CmEE}$ in mice.

\section{Materials and methods Collection and identification of plant material}

The leaves and stems of C. micranthum were collected from Idofian near Ilorin, Kwara State, Nigeria. The identification and authentication was performed by Mr. Bolu Ajayi of the Department of Plant Biology, Faculty of Life Sciences, University of Ilorin, Ilorin. A voucher specimen number (U1LH/001/910) was allocated to the plant and thereafter deposited at the herbarium of the Department of Plant Biology, Faculty of Life Sciences, University of Ilorin, Ilorin. 


\section{Drugs and chemicals}

The chemicals and reagents such as diazepam (IM; Roche, Nigeria), methylated spirit (MOKO), normal saline $100 \mathrm{~mL}$ (Drugfield Pharmaceuticals Ltd. Nigeria), ethanol and distilled water (freshly prepared in our laboratory) used for this work were of analytical grade and purchased from recognised chemical manufacturers and suppliers.

\section{Experimental animals}

Fifty-six male and female Swiss albino mice weighing $20 \mathrm{~g}-30 \mathrm{~g}$ were procured from the Central Animal House of the University of Ilorin, Ilorin. Animals were housed in groups of five in cages (41 length $\times 25$ width $\times 25$ height $) \mathrm{cm}$ with $12 / 12$ h-light/dark cycle in the animal holding of the Department of Pharmacology and Toxicology, University of Ilorin, Ilorin. The animals got acclimatised for a week before they were used for the experiments. However, during this time, they had free access to standard mouse feed (Metrotech Nigeria Limited, Nigeria) and water ad libitum.

\section{Preparation of ethanolic leaf extract of Combretum micranthum}

The fresh leaves of C. micranthum were washed thoroughly with water and air-dried under shade at room temperature, then coarsely powdered. In order to obtain the ethanolic extract, $900 \mathrm{~g}$ powder of C. micranthum leaves was boiled in $2 \mathrm{~L}$ of $95 \%$ ethanol under reflux and then extracted with ethanol by maceration for a period of $48 \mathrm{~h}$. Subsequently, the mixture was filtered using Whatman filter paper 1.0. The resultant filtrate was concentrated over the vapour of the water bath at $45{ }^{\circ} \mathrm{C}$ and dried under vacuum (Amali et al. 2019). The percentage yield of extracts was calculated as:

Percentage yield $=\frac{\text { Weight of extract }}{\text { Weight of plant material }} \times 100$

[Eqn 1]

\section{Acute toxicity study}

The acute toxicity study of the ethanolic leaf extract was conducted according to the Organization for Economic Cooperation and Development (OECD)-423 guidelines (2001). Six $(n=6)$ mice were obtained and allowed to acclimatise for a week. Mice were not given food overnight prior to the conduct of the experiment but however provided with water only. They were rather fed after $4 \mathrm{~h}$ following oral administration of the extract during the conduct of the acute toxicity study. The animals were administered $2000 \mathrm{mg} / \mathrm{kg}$ orally and observed for some signs of toxicity (such as skin changes, morbidity, aggressiveness, increase oral secretion, sensitivity to sound, pain as well as respiratory movements and mortality) at regular intervals of $0.5,1,2,4,8,12,24 \mathrm{~h}$ and daily for 2 weeks.

\section{Behavioural studies}

\section{Open field test}

Novelty-induced behaviours (NIBs) including locomotion, rearing and grooming were assessed in mice according to the procedures of Akanmu et al. (2011). A total of twenty five (25) mice were randomly distributed into five groups $(n=5)$ and treated as follows: Groups I - III were orally administered 500, 1000 and $2000 \mathrm{mg} / \mathrm{kg}$ of $\mathrm{CmEE}$, respectively. Groups IV and V were administered $1 \mathrm{mg} / \mathrm{kg}$ diazepam intraperitoneally as (positive control) and normal saline $0.5 \mathrm{~mL}$ orally (negative control), respectively. Thereafter, the three NIBs were observed using the open field box and scored for 10 min per session. Locomotion (horizontal movement of mouse across the floor of square units of the observation cage with all paws- (Irwin 1968), rearing (standing of the mouse on its hind legs or with its forearm against the wall of the observation cage or in the free air) and grooming (body cleaning with paws picking of the body and pubis with mouth and face washing actions). The cage was cleaned with methylated spirit before the introduction of another animal therein to eliminate the olfactory cue that may have been left behind by the previous animals.

\section{Anxiolytic model}

Elevated plus maze: Another set of mice $(n=25)$ was arranged and treated like that of the open field test (OFT). The effect of the extract on the frequency of entry of mice into the open and closed arms and time spent in each of the arms of the maze were observed for $6 \mathrm{~min}$ and recorded (Vogel et al. 2002). The principle of EPM is based on the natural conflict in mice between the drive to explore a new environment and the tendency to avoid a potentially dangerous area (Ramos et al. 2008; Rodgers \& Cole 1994). The test has been proposed for selective identification of anxiolytic and anxiogenic compounds (Lister 1987). It consists of a plus-shaped maze, elevated from the floor with two open arms and two closed arms opposite to each other inter-connected by a central platform. Time spent in the unprotected open arms and percentage of entries in the open arms in relation to the total number of arm entries are used as experimental indices of anxiety, whereas the entries in the closed arms are seen as indices of general locomotion (Lister 1990). The index of open arm avoidance, interpreted as level of anxiety (Trullas \& Skolnick 1993) was calculated as:

$\left[\frac{100-(\% \text { time on open arm }+\% \text { entries into open arm })}{2}\right]$ [Eqn 2]

If result is at least 10 point < than vehicle, the sample is anxiolytic, conversely if result is at least 10 points $>$ saline (vehicle), then the sample will be considered anxiogenic.

\section{Statistical analysis}

The data were expressed as mean \pm standard error of mean (S.E.M). The data were statistically analysed using Student's- $t$ test and one way analysis of variance (ANOVA) and the Student-Newman-Keuls test. The value of $p<0.05$ was considered as significant.

\section{Ethical consideration}

Ethical clearance was obtained from the University of Ilorin Ethical Review Committee (UERC/ASN/2019/1604). All experiments were carried out in accordance with the guidelines for laboratory procedures laid down by the UERC, 
Ilorin, International Animal Care and Use Committee (IACUC) in Nigeria and National Institute of Health (NIH, 1985). Leaves collected were authenticated and deposited at the herbarium of the Department of Plant Biology, University of Ilorin, Ilorin with a voucher number U1LH/001/910.

\section{Results}

\section{Plant extract yield}

The percentage yield of the $C m E E$ was $14.28 \% \mathrm{w} / \mathrm{w}$ as shown in the calculation here:

Percentage yield of extract $=\frac{\text { Weight of extract }(\mathrm{g})}{\text { Weight of powdered CM leaves }(\mathrm{g})} \times 100$

$$
\begin{aligned}
& =\frac{65 \mathrm{~g}}{455 \mathrm{~g}} \times 100 \\
& =14.28 \% \mathrm{~W} / \mathrm{W}
\end{aligned}
$$

[Eqn 3]

TABLE 1: Result of acute toxicity assay of ethanolic leaf extract of Combretum micranthum at a dose of $2000 \mathrm{mg} / \mathrm{kg}$ using Organization for Economic Cooperation and Development method.

\begin{tabular}{lcc}
\hline Number of animals & Dose $(\mathrm{mg} / \mathrm{kg})$ & Mortality \\
\hline 6 & 2000 & Nil \\
\hline
\end{tabular}

Thus, $C m E E$ displayed very low toxicity for oral administration in mice at $\mathrm{LD}_{50} \geq 2000 \mathrm{mg} / \mathrm{kg}$.

\section{Determination of acute toxicity of Combretum micranthum}

No death of mice from the administration of tested doses of $\mathrm{C} m \mathrm{EE}$ was recorded. Similarly, no toxic effect (acute or delayed) or changes in the skin, morbidity, lethargy or exhibition of aggressiveness, increase in oral secretion, uncoordinated sensitivity to sound, pain and respiratory movements was observed at the dose of $2000 \mathrm{mg} / \mathrm{kg}$ administered to the group of animals $(n=6)$ throughout the period of observation ( 2 weeks) according to the OECD guideline. This suggests that even the highest dose tested in this study is not toxic acutely. Thus, the lethality range of $C m E E$ in mice was found to be $>2000 \mathrm{mg} / \mathrm{kg}$ according to the OECD guidelines.

\section{Behavioural study}

The groups of mice administered CmEE at 500, 1000 and $2000 \mathrm{mg} / \mathrm{kg}$ exhibited decreased frequency of locomotion $p<0.05$ in mice when compared with the saline group as shown in Figure 2a. Significant decrease in number of rearing but nonetheless, increase in indices of grooming (although not significant) was only observed in mice administered $2000 \mathrm{mg} / \mathrm{kg}$ of $\mathrm{CmEE}$ when compared with the saline group as depicted in Figure $2 b$ and $c$.

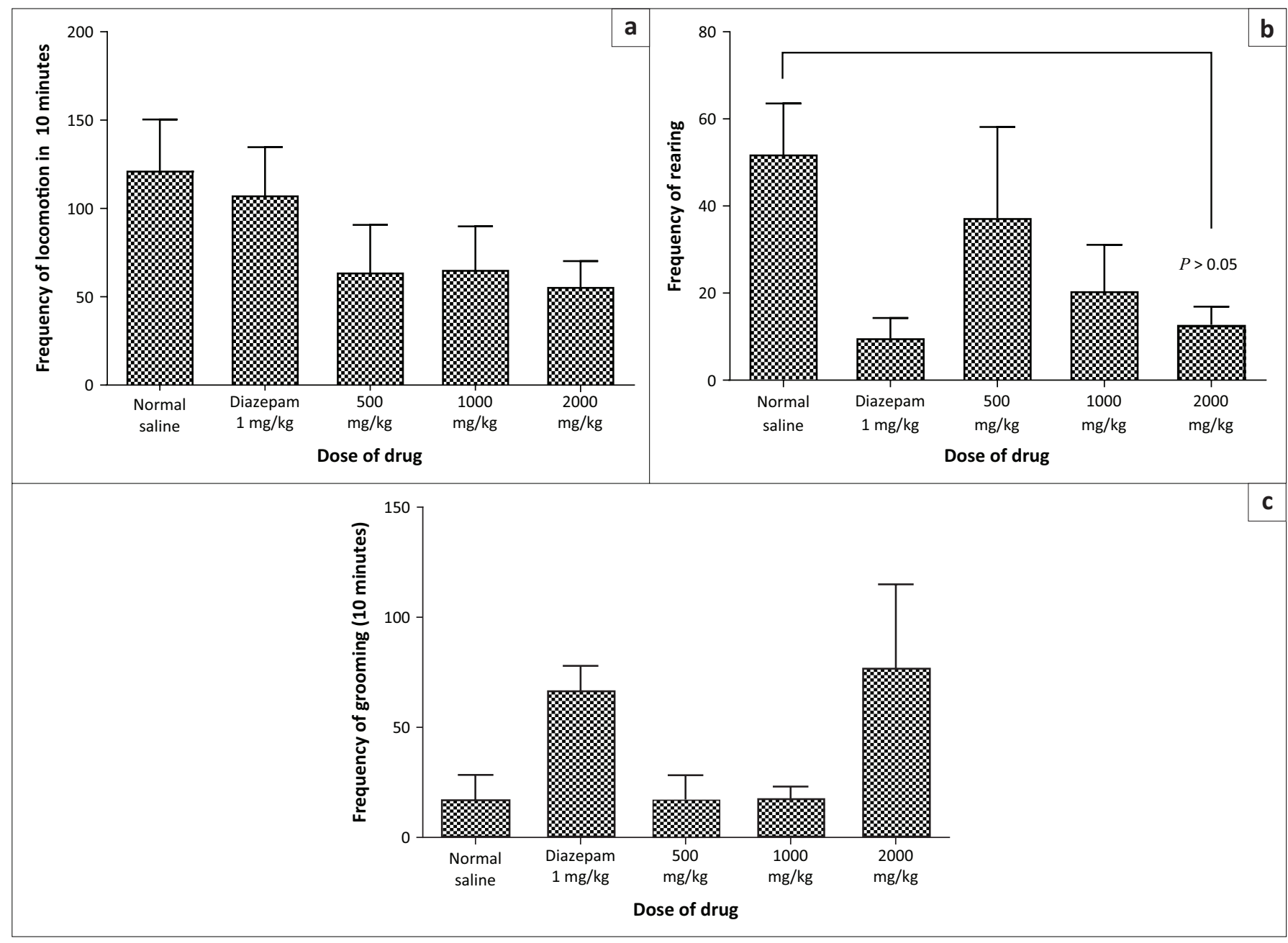

FIGURE 2: Frequency of grooming in mice administered 500, 1000 and $2000 \mathrm{mg} / \mathrm{kg}$ of ethanolic leaf extract of Combretum micranthum, $1 \mathrm{mg} / \mathrm{kg}$ diazepam and normal saline in mice. Data are expressed as mean \pm standard error of mean (S.E.M.) and analysed using one-way analysis of variance (ANOVA) with $p<0.05$ considered as significant. 


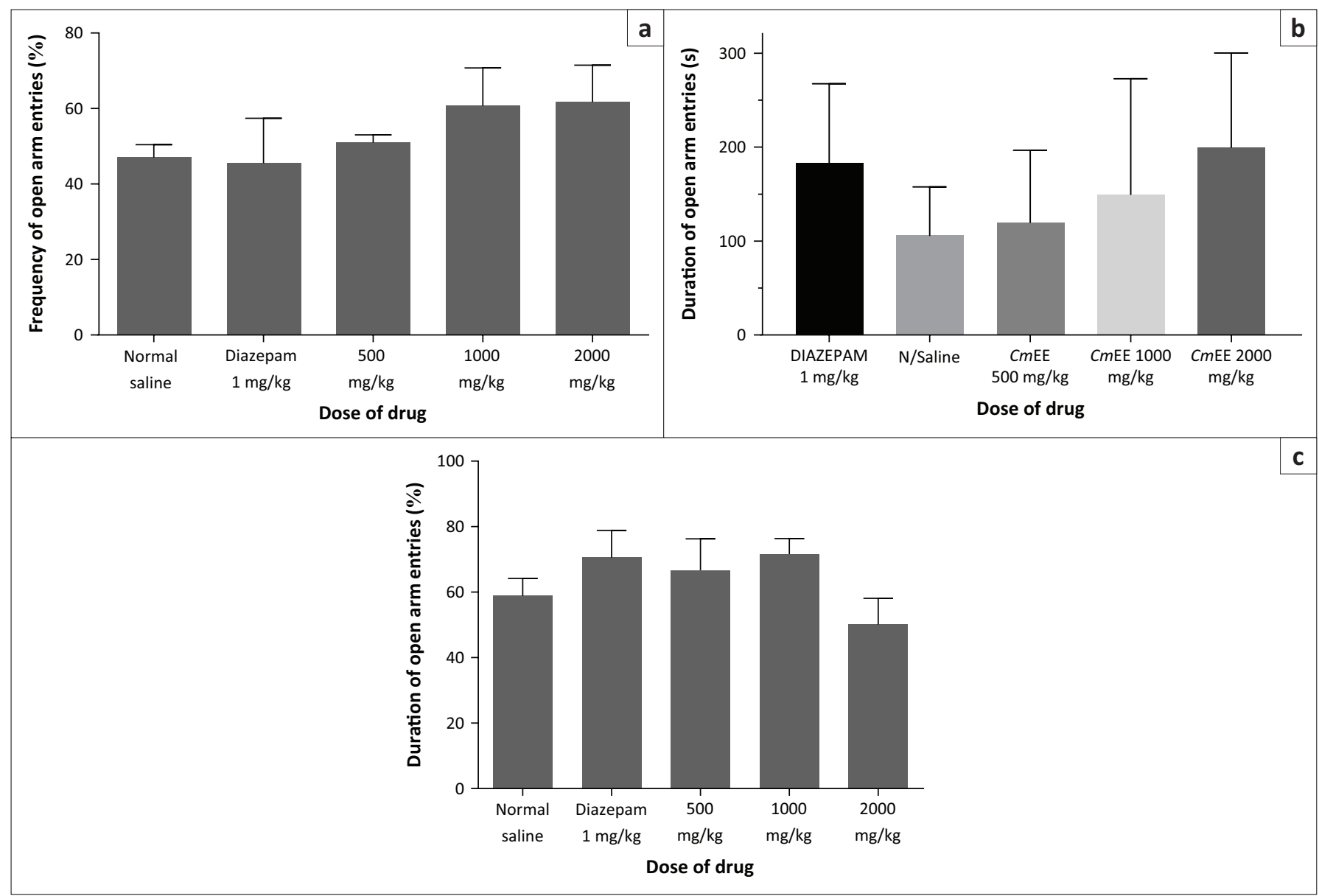

FIGURE 3: Assessment of the frequency and duration of entries into the open arm of the elevated plus maze in mice administered 500,1000 and $2000 \mathrm{mg} / \mathrm{kg}$ of ethanolic leaf extract of Combretum micranthum, $1 \mathrm{mg} / \mathrm{kg}$ diazepam and normal saline in mice. (a) The frequency (b) duration in seconds and (c) percent of the total time spent in the open arms of the elevated plus maze in response to ethanolic leaf extract of $C$. micranthum, diazepam and normal saline in mice. Data are expressed as mean \pm standard error of mean (S.E.M.) and analysed using Student's- $t$ test with $p<0.05$ considered as significant.

\section{Anxiolytic study}

\section{Assessment of the frequency and duration of entries into the open arm of elevated plus maze}

The increments observed in the frequency of exploration in the open arm (Figure 3a) by the mice at any of the treated groups under consideration $(500,1000$ and $2000 \mathrm{mg} / \mathrm{kg}$ ) were not significantly different from the normal saline control group as shown in Figure 3a.

Contrarily, the groups administered 500, 1000 and $2000 \mathrm{mg} / \mathrm{kg}$ of $C m$ EE showed increased percentage time spent in the open arm in a dose-dependent pattern $(33.3 \%, 41.6 \%$ and $55.4 \%$, respectively) when compared with the saline group as shown in Figure $3 b$ and c. This observation suggests the presence of anxiolytic property in the $\mathrm{CmEE}$.

\section{Assessment of the index of open arm avoidance on elevated plus maze}

Similarly, there were significant decreases considered to be dose-dependent in the indices of open arm avoidance in groups administered $1000 \mathrm{mg} / \mathrm{kg}$ (48.9) and $2000 \mathrm{mg} / \mathrm{kg}$ (41.4) of $\mathrm{CmEE}$. However, there was a noticeable decrease in the index of open arm avoidance at $1000 \mathrm{mg} / \mathrm{kg}$ and $2000 \mathrm{mg} / \mathrm{kg}$ (Table 2). This is suggestive of an aversion that can be interpreted as an anxiolytic effect.
TABLE 2: Index of open arm avoidance values of ethanolic extracts of controls and ethanolic extract of Combretum micranthum.

\begin{tabular}{lccc}
\hline Treatment group & $\begin{array}{c}\text { Frequency of } \\
\text { entries (\%) }\end{array}$ & $\begin{array}{c}\text { Time spent in the } \\
\text { open arms (\%) }\end{array}$ & $\begin{array}{c}\text { Index of open } \\
\text { arm avoidance }\end{array}$ \\
\hline Normal saline & 59.9 & 23.6 & 58.3 \\
Diazepam & 47.0 & 50.8 & 51.1 \\
$500 \mathrm{mg} / \mathrm{kg}$ & 51.0 & 33.3 & 57.9 \\
$1000 \mathrm{mg} / \mathrm{kg}$ & 60.7 & 41.6 & 48.9 \\
$2000 \mathrm{mg} / \mathrm{kg}$ & 61.7 & 55.4 & 41.4 \\
\hline
\end{tabular}

\section{Discussion}

Anxiety is an emotional, naturally occurring condition of uncontrolled fear usually triggered by both internal and external components (Psychiatry.org 2018). It entails characteristic motor disturbances, sympathetic hyperactivity and excessive apprehension (Sadock \& Sadock 2003). It also disrupts behavioural, learning and cognitive processes (Pine, Wasserman \& Workman 1999; Ravindran \& Stein 2010; Schweizer \& Rickels 1997). As a result of the several adverse effects of conventional drugs such as benzodiazepines, barbiturates, etc. (Bandelow et al. 2002; Lopez-munoz, Ucha-udabe \& Alamo 2005; Otto 1993), compliance tendencies by patients have reduced (Sheehan et al. 1980) thereby limiting their immense therapeutic benefits (Davidson 2001; Koen \& Stein 2011). Consequently, interest in medicinal 
plants and therapeutic agents of natural origin have increased recently (Kunovac \& Stahl 1995), thus alternative therapies are being sought (Ajao et al. 2016). In fact, the use of herbs has evolved as the most common form of complementary and alternative therapy included in the management of anxiety disorders (Johnson et al. 2010). Despite the traditional use of the $\mathrm{CmEE}$ in the management of anxiety disorders, its anxiolytic effect has not been reported. Our study therefore evaluated the acute toxicity, behavioural effect and anxiolytic potential of the $\mathrm{CmEE}$ in mice.

The fraction extracted from a crude plant sample is usually dependent on the polarity of solvent used in the extraction process (Banfi et al. 2014). The dried powder (900 g) of C. micranthum leaves yielded $128.52 \mathrm{~g}$. In other words, the percentage yield of $\mathrm{CmEE}$ was $14.28 \% \mathrm{w} / \mathrm{w}$. This relatively high yield is similar to the amount reported by Banfi et al. (2014) and Yapo et al. (2014) where ethanol and water were used as solvents for extraction. Thus, its practical application is well envisaged should the herb (as a drug candidate) be developed into a therapeutic agent. The tested doses of $\mathrm{CmEE}$ displayed no mortality (Table 1). This was shown by the high $\mathrm{LD}_{50}$ value obtained from its oral administration in mice. Therefore, the absence of toxic symptoms or reactions even at the highest dose of $2000 \mathrm{mg} / \mathrm{kg}$ and when observed over a relatively long period of time suggest its harmless nature. Hence, it could be said to belong to Category 5 of the Globally Harmonised System (GHS) according to the guidelines of classification of chemicals by Organization for Economic and Community Development (OECD 2001). This observation corroborates an earlier work by Masoko et al. (2010), Abdullahi et al. (2014) and Muttaka, Jamilu and Sani (2016) where aqueous extract of $C$. micranthum was studied. This may therefore justify its continuous use in trado-medical practice as an indication for anxiolytic disorders without any toxic incidence recorded over the years. The route of administration of an extract or drug may significantly influence its level of toxicity (Al-Ali et al. 2008). Danmalam et al. (2017) and Kpemissi et al. (2020) had reported non-toxic effect of $C$. micranthum when administered to rodents even at $5000 \mathrm{mg} / \mathrm{kg}$. Our study revealed however that oral route of administration of $\mathrm{CmEE}$ to rodents did not influence its toxicity. This may be an advantage should it be considered for development as a drug candidate.

Generally speaking, both locomotor and rearing activities of mice are suggestive of explorative tendency and thereby considered as central excitatory behaviours (Ajayi \& Ukponmwan 1994). Considering the observations made on behavioural studies, C. micranthum at all tested doses produced decrease in frequency of locomotion although not significant as depicted in Figure 2a. Hitherto, no record of behavioural changes such as aggressiveness was recorded in mice during toxicity study, thereby corroborating the less prominent decrease in frequency of locomotion as observed. Similarly, there was significant decrease $(p<0.05)$ in the number of rearing at $2000 \mathrm{mg} / \mathrm{kg}$ when compared with the saline group as shown in Figure $2 b$. The reduction observed in frequency of locomotion and number of rearing by the administration of $\mathrm{CmEE}$ in mice may suggest its central inhibitory action on excitatory neural mechanisms such as glutamatergic and dopaminergic pathways (Akanmu et al. 2011). Otherwise, there may be possible potentiation of the central inhibitory pathways, for example, $\gamma$-aminobutyric acid (GABA). It could be inferred from the results obtained that the tested doses of $C m E E$ have central inhibitory activities although mild. Meanwhile, a study has reported the inhibitory central nervous system activity of C. micranthum (Danmalam et al. 2011) albeit at higher doses. Surprisingly, the indices of grooming was rather increased at $2000 \mathrm{mg} / \mathrm{kg}$ of $\mathrm{CmEE}$ when compared with the negative control as shown in Figure 2c contrary to the reduction in number of locomotion and rearing activities. Nevertheless, this unexpected outcome (Rodgers et al. 1992) should inspire further probe into the effects of $\mathrm{CmEE}$ on grooming indices. The changes observed in novelty-induced parameters, although not well prominent indicate behavioural-modulating property of C. micranthum in mice (Griebel et al. 1993). This may justify the presence of centrally-acting phytochemicals in the plant extract as previously reported (Carr et al. 2006; Cara et al. 2010; Coulidiati et al. 2011; Halilu et al. 2016; Manzo et al. 2017), which may act perhaps via different mechanisms (Dawson \& Watson 2009; Hayes \& Schulz 1987).

Furthermore, the elevated plus maze is widely being considered a suitable model for evaluating anxiolytic or anxiogenic potentials of substances in rodents (Amali et al. 2019). It was originally developed by Pellow et al. (1985) and its principle is largely based on the innate aversion of rodents to heights and open spaces. Generally speaking, an anxious rodent prefers the closed arms, thereby spends a relatively longer time therein but little time in the open arms and vice versa. Therefore, anxiolytic drugs increase the time spent in the open arms and increase the number of open arm entries during the test (Akanmu et al. 2011). These responses have to be unconditioned to prevent bias, thus enabling optimal measurement of anxiety in the animal (Clement \& Chapouthier 1998). In this model, it has been proven that the amount of time spent in the closed and open arms can be interpreted into the anxiolytic state of the animal (Clement \& Chapouthier 1998; Griebel et al. 1993). The model was therefore employed to further evaluate the effects of ethanolic leaf extract of $C$. micranthum in mice. None of the tested doses of ethanolic leaf extract of $C$. micranthum was found to have a significant effect either on the frequency of the open or closed arm entries as shown in Figure $3 \mathrm{a}$. Contrarily, all the extract-treated groups showed significant increase in percentage time spent in the open arm in a dosedependent pattern when compared with the saline group as shown in Figure $3 b$ and c. Similarly, the determination of the 'index of open arm avoidance' revealed significant decreases in dose-dependency in the groups treated with 1000 and $2000 \mathrm{mg} / \mathrm{kg}$ of CmEE when compared with saline group as presented in Table 2. This is suggestive of an aversion that can be interpreted as an anxiolytic effect (Trullas \& Skolnick 1993). Hence, 1000 and $2000 \mathrm{mg} / \mathrm{kg}$ of 
CmEE showed dose-dependent anxiolytic potentials in mice. These findings therefore justify the ethnomedicinal use of C. micranthum in the management of anxiety disorders. Thus, C. micranthum could be considered a promising 'lead' drug to be developed as a therapeutic agent indicated in anxiety disorders.

\section{Conclusion}

This study evaluated the acute toxicity, behavioural effect and anxiolytic potential of the $C m E E$ in mice. The $C m E E$ is a non-toxic herbal regimen. The preliminary data indicated that it modulates behavioural paradigm and possesses a dose-dependent anxiolytic effect in mice. Hence, our findings have therefore provided scientific basis for its ethnomedicinal use in anxiety disorders. However, further studies to ascertain the effects of $\mathrm{CmEE}$ on features of grooming, characterisation of possible neurotransmitters and elucidation of specific receptors or pathway(s) involved in its neural mechanism(s) of action are thus recommended.

\section{Acknowledgements}

Authors appreciate laboratory staff of the Department of Pharmacology and Toxicology for their technical assistance and Mr Bolu-Ajayi of the Department of Botany, Faculty of Life Sciences, University of Ilorin, Ilorin, Nigeria for plant collection, identification and authentication.

\section{Competing interests}

The authors have declared that they have no financial or personal commitments, which may have inappropriately influenced their opinions and views in presenting this article.

\section{Authors' contributions}

M.O.A designed, supervised the project, performed data analysis and interpretation and critically revised the manuscript. S.A.A. coordinated the laboratory experiments, drafted and substantially revised the manuscript. Q.A.O. and E.O.O. collected plant materials, prepared samples, carried out the experiments and drafted the manuscript whilst A.I.O. participated in some of the laboratory experiments. Authors read and approved the final manuscript.

\section{Funding information}

The authors received no funding whatsoever for the research, authorship and publication of this article.

\section{Data availability statement}

The raw data generated from this study and upon which our conclusions are based are available and could be requested from the corresponding author should the need arises.

\section{Disclaimer}

The authors are solely responsible for the views shared in this article.

\section{References}

Abdel Kader, A.S., Maârouhi, I.M., Oumarou, S.S., Djibo, A.K., Diadié, H.O. Abdoulahi, M.A. et al., 2020, 'Evaluation of antibacterial activity from extract of three plant species on strains of salmonella in Niger', World Journal of Pharmacy and Pharmaceutical Sciences 9(3), 462-481.

Abdullahi, M.H., Anuka, J.A., Yaro, A. \& Musa, A., 2014, 'Effect of aqueous leaf extract of Combretum Micranthum G. Don (Combretaceae) on gastrointestinal smooth muscle', Bayero Journal of Pure and Applied Sciences 7(2), 21-25. https://doi. org/10.4314/bajopas.v7i2.5

ADAA, 2018, Understand the facts/anxiety and depression association of America ADAA, viewed 06 April 2018, from https://adaa.org/understanding-anxiety.

Ajao, M.S., Imam, A., Amin, A., Abdulmajeed, W.I., Ajibola, M.I., Alli-Oluwafuyi, A. et al., 2016, 'Black seed oil improves motor and anxiety-like behaviors and cerebellar cyto-architectonic in adult male wistar rats', Nigerian Journal of Neuroscience 8(1-2), 8-14.

Ajayi, A.A. \& Ukponmwan, O.E., 1994, 'Evidence of angiotensin II and endogenous opioid modulation of NIR in the rat', African Journal of Medicine \& Medical Sciences 23(3), 287-290.

Akanmu, M.A., Olowookere, T.A., Atunwa, S.A., Ibrahim, B.O., Lamidi, O.F., Adams, P.A et al., 2011, 'Neuropharmacological effects of Nigerian honey in mice', African Journal of Traditional, Complementary, and Alternative Medicine 8(3), 230-249. https://doi.org/10.4314/ajtcam.v8i3.65285

Al-Ali, A., Alkhawajah, A., Randhawa, M.A. \& Shaikh, N.A., 2008, 'Oral and intraperitoneal $\mathrm{LD}_{50}$ of thymoquinone, an active principle of Nigella Sativa, in mice and rats', Journal of Ayub Medical College, Abbottabad: JAMC 20(2), 25-27.

Amali, M.O., Atunwa, S.A., Aiyelero, M.O., Usman, S.O., Olapade, A.I., Oyedotun, E.O. et al., 2019, 'Acute toxicity study and evaluation of the anxiolytic activity of the ethanol leave extract of Bryophyllum Pinnatum (Kurz) in mice', Journal of Pharmaceutical Research, Development and Practice 3(1), 27-35.

American Psychiatric Association, 2000, Diagnostic and statistical manual of mental disorders: DSM-IV-TR, 4th edn., pp. 429-430, Test revision, American Psychiatric Association, Washington, DC.

Arumugam, G., Manjula, P. \& Paari, N., 2013, 'A review: Anti diabetic medicinal plants used for diabetes mellitus', Journal of Acute Disease 2(3), 196-200. https://doi. org/10.1016/S2221-6189(13)60126-2

Bandelow, B. \& Michaelis, S., 2015, 'Epidemiology of anxiety disorders in the 21st century', Dialogues in Clinical Neuroscience 17(3), 327-335.

Bandelow, B., Zohar, J., Hollander, E., Kasper S., Möller H. \& WFSBP Task Force on Treatment Guidelines for Anxiety, Obsessive-Compulsive and Posttraumatic Stress Disorders, 2002, 'World Federation of Societies of Biological Psychiatry (WFSBP) guidelines for the pharmacolical treatment of anxiety, obsessive-compulsive guidelines for the pharmacological treatment of anxiety, obsessive-compulsive and posttraumatic stress disorders', The World Journal of Biological Psychiatry
3(4), 171-199. https://doi.org/10.3109/15622970209150621

Banfi, S., Caruso, E., Orlandi, V., Barbieri, P., Cavallari, S., Viganò, P. et al., 2014 'Antibacterial activity of leaf extracts from Combretum micranthum and Guiera senegalensis (Combretaceae)', Research Journal of Microbiology 9(2), 66-81. https://doi.org/10.3923/jm.2014.66.81

Billings, C., 1986, 'Diagnosis and treatment of anxiety disorders', American Journal of Psychiatry 143(2), 252-253. https://doi.org/10.1176/ajp.143.2.252

Bisso, S., Cornara, L., Varnier, O., Banfi, S., Caruso, E., Dermott, J. et al., 2015, 'Pharmacognostic study and antiviral properties of Combretum micranthum', in Congresso Societa Botanica Italiana, a poster presented at the 110th Congress of Italian Botanical Society in Milan, Italy, September 2015

Bourin, M. \& Thibaut, F., 2013, 'A critical approach of the current treatment of anxiety disorders', Current Psychopharmacology 2(2), 104-112. https://doi. org/10.2174/2211556011302020002

Burkill, H.M., 1985, 'Combretum micranthum G. Don [Family Combretaceae]' Global Plants, viewed 10 August 2018, from https://plants.jstor.org/stable/ history/10.5555/al.ap.upwta.1_774.

Bystritsky, A., Khalsa, S.S., Cameron, M.E. \& Schiffman, J., 2013, 'Current diagnosis and treatment of anxiety disorders', Pharmacy \& Therapeutics 38(1), 30-38, $41-44,57$.

Calixto, J.B., 2000, 'Efficacy, safety, quality control, marketing and regulatory guidelines for herbal medicines (phytotherapeutic agents)', Brazilian Journal of Medical and Biological Research 33(2), 179-189. https://doi.org/10.1590/S0100 $879 \times 2000000200004$

Cara, R.W., 2010, 'Chemistry and pharmacology of Kinkeliba (Combretum micranthum), A West African Medicinal Plant', presented to Rutgers University, New Brunswick, NJ.

Carr, M.N., Bekku, N. \& Yoshimura, H., 2006, 'Identification of anxiolytic ingredients in ginseng root using the elevated plus-maze test in mice', European Journal of Pharmacology 531(1-3), 160-165. https://doi.org/10.1016/j. ejphar.2005.12.014

Chika, A. \& Bello, S.O., 2010, 'Antihyperglycaemic activity of aqueous leaf extract of Combretum micranthum (Combretaceae) in normal and alloxan-induced diabetic rats', Journal of Ethnopharmacology 129(1), 34-37. https://doi.org/10.1016/j. jep.2010.02.008

Clement, Y. \& Chapouthier, G., 1998, 'Biological bases of anxiety', Neuroscience and Biobehavioral Reviews 22(5), 623-633. https://doi.org/10.1016/S01497634(97)00058-4

Coulidiati, T.H., Millogo-Koné, H., Lamien-Méda, A., Yougbaré-Ziébrou, M., MilogoRasolodimby, J. \& Nacoulma, O.G., 2011, 'Antioxidant and antibacterial activities 
of two combretum species from Burkina Faso', Research Journal of Medicinal Plant 5(1), 42-53. https://doi.org/10.3923/rjmp.2011.42.53

Danmalam, U.H., Agunu, A., Abdulrahman, E.M., Ilyas, N., Magaji, M.G. \& Yaro, A.H., 2017, 'Anticonvulsant studies on a traditional antiepileptic mixture used by the Hausa people of north-western Nigeria', Research Journal of Pharmacognosy (RJP) $4(3), 13-19$

Danmalam, U.H., Idoko, V.E., Yaro, A.H., Magaji, M.G., Agunu, A. \& Abdulrahman, E.M., 2011, 'Phytochemical and anticonvulsant screening of the aqueous ethanol extract of Combretum micranthum G. Don Root', Nigerian Journal of Pharmaceutical Science 10(1), 32-38.

Davidson, J.R., 2001, 'Pharmacotherapy of generalized anxiety disorder', Journal of Clinical Psychiatry 62(Suppl 11), 46-50. discussion, 51-52.

Dawson, L.A. \& Watson, J.M., 2009, 'Vilazodone: A 5- $\mathrm{HT}_{1 \mathrm{~A}}$ receptor agonist/serotonin transporter inhibitor for the treatment of affective disorders', CNS Neuroscience Therapeutics 15(2), 107-117. https://doi.org/10.1111/j.1755-5949.2008.00067.x

Eloff, J.N., Katerere, D.R. \& McGaw, L.J., 2008, 'The biological activity and chemistry of the Southern African Combretaceae', Journal of Ethnopharmacology 119(3), 686-699. https://doi.org/10.1016/j.jep.2008.07.051

Fern, K., 2014, 'Combretum micranthum useful tropical plants', Tropical.the ferns. Info, viewed 14 August 2018, from https://tropical.theferns.info/viewtropical. php?id=Combretum+micranthum.

Ferrea, G., Canessa, A., Sampietro, F., Cruciani, M., Romussi, G. \& Bassetti, D., 1993 In vitro activity of a Combretum micranthum extract against herpes simplex virus types 1 and 2', Antiviral Research 21(4), 317-325. https://doi.org/10.1016/01663542(93)90010-G

GBD, 2015, 'Neurological disorders collaborator group. Global, regional, and national burden of neurological disorders during 1990-2015: A systematic analysis for the Global Burden of Disease Study 2015', The Lancet Neurology 16(11), 877-897.

Gill, L.S., 1992, Ethno-medicinal uses of plant in Nigeria, p. 46, UNIBEN Press, Benin-City.

Griebel, G., Belzung, C., Misslin, R. \& Vogel, E., 1993, 'The free exploratory paradigm: And effective method for measuring neurophobic behavior in mice and testing potential neophobia-reducing drugs', Behavioural Pharmacology 4(6), 637-644. potential neophobia-reducing drugs', Behavioural Ph
https://doi.org/10.1097/00008877-199312000-00009

Halilu, M.E., Yahaya, M., Dangoggo, S.M., Umar, K.J., Ibrahim, G., Abdullahi, M.I., Uba, A.S. et al., 2016, 'Isolation and characterization of di-(2-ethylhexyl) phthalate from the leaves of Combretum micranthum (Altum) combretaceae', International Journal of Science for Global Sustainability 2(2), 15-20.

Hayes, P.E. \& Schulz, S.C., 1987, 'Beta-blockers in anxiety disorders', Journal of Affective Disorders 13(2), 119-130. https://doi.org/10.1016/0165-0327(87)90017-6

Irwin, S., 1968, 'Comprehensive observational assessment: la. A systematic, quantitative procedure for assessing the behavioral and physiologic state of the mouse',

Jared, M.O., Bibiane, A.W., Gervason, A.M., Lameck, N.A. \& Japhet, K.N., 2018 , 'The antibacterial, antioxidant and phytochemical composition of Combretum tanaense (J. Clark) root extracts', European Journal of Medicinal Plants 23(4), 1-8. https://doi.org/10.9734/EJMP/2018/40956

Johnson, P.L., Truitt, W., Fitz, S.D., Minick, P.E., Dietrich, A. \& Sanghani, S., 2010, 'A key role for orexin in panic anxiety', Nature Medicine 16(1), 111-115. https://doi. org/10.1038/nm.2075

Koen, N. \& Stein, D.J., 2011, 'Pharmacotherapy of anxiety disorders: A critical review', Dialogues in Clinical Neuroscience 13(4), 423-437.

Kpemissi, M., Metowogo, K., Melila, M., Veerapur, V.P., Negru, M., Taulescu, M. et al., 2010, 'Acute and subchronic oral toxicity assessments of Combretum micranthum (Combretaceae) in Wistar rats', Toxicology Reports 7, 162-168. https://doi. org/10.1016/j.toxrep.2020.01.007

Kumar, H., More, S.V., Han, S.D., Choi, J.Y. \& Choi, D.K., 2012, 'Promising therapeutics with natural bioactive compounds for improving learning and memory review of randomized trials', Molecules 17(9), 10503-10539. https://doi.org/10.3390/ molecules170910503

Kunovac, J.L. \& Stahl, S.M., 1995, 'Future directions in anxiolytic pharmacotherapy', Psychiatric Clinics of North America 18(4), 895-909. https://doi.org/10.1016/ S0193-953X(18)30030-3

Lister, R.G. 1987, 'The use of a plus-maze to measure anxiety in the mouse', Psychopharmacology 111, 323-333. https://doi.org/10.1007/BF00177912

Lister, R.G., 1990, 'Ethologically-based animal models of anxiety disorders', Pharmacology \& Therapeutics 46(3), 321-340. https://doi.org/10.1016/0163 7258(90)90021-S

Lopez-munoz, F., Ucha-udabe, R. \& Alamo, C., 2005, 'The history of barbiturates a century after their clinical introduction', Neuropsychiatric Disease and Treatment $1(4), 329-343$.

Manzo, L.M., Moussa, I. \& Ikhiri, K., 2017, 'Phytochemical screening of selected medicinal plants used against diarrhea in Niger, West Africa', International Journa of Herbal Medicine 5(4), 32-38. https://doi.org/10.15171/ijep.2017.13

Martin, P., 2003, 'The epidemiology of anxiety disorders: A review', Dialogues in Clinical Neuroscience 5(3), 281-298.

Masoko, P., Picard, J., Howard, R.L., Mampuru, L.J. \& Eloff, J.N., 2010, 'In vivo antifungal effect of Combretum and Terminalia species extracts on cutaneous wound healing in immunosuppressed rats', Pharmaceutical Biology 48(6), 621-632. https://doi. org/10.3109/13880200903229080
Mohammed, Z.M., Haruna, Z.K., Abdullah, Z.I., Hussein, S.A., Kurfi, B.G., Habila, J.D. et al., 2020, 'Effect of Combretum micranthum methanol leaf extract against exposure to lead on behavioural activities in mice', Journal of Biomedical and Therapeutic Sciences 7(1), 1-6.

Moser, D.K., 2007, 'The rust of life: Impact of anxiety on cardiac patients', American Journal of Critical Care 16(4), 361-369. https://doi.org/10.4037/ajcc2007.16.4.361

Muttaka, A., Jamilu, L.A. \& Sani, S.M., 2016, 'Toxicological studies of the aqueous leaves extracts of Combretum micranthum on rats', The International Journal of Biotechnology \& Biochemistry 12(2), 167-171.

OECD, 2001, Guidelines for the testing of chemicals, p. 423, OECD/OCDE, Paris.

Otto, M.W., 1993, 'Discontinuation of benzodiazepine treatment: Efficacy of cognitive-behavioral therapy for patients with panic disorder', American Journa of Psychiatry 150(10), 1485-1490. https://doi.org/10.1176/ajp.150.10.1485

Pellow, S., Chopin, P., File, S.E. \& Briley, M., 1985, 'Validation of open: Closed arm entries in an EPM as a measure of anxiety in the rat', Journal of Neuroscience Methods 14(3), 149-167. https://doi.org/10.1016/0165-0270(85)90031-7

Pine, D.S., Wasserman, G.A. \& Workman, S.B., 1999, 'Memory and anxiety in perpubertal boys at risk for delinquency', Journal of the American Academy of Child and Adolescent Psychiatry 38(8), 1024-1031. https://doi.org/10.1097/00004583199908000-00019

Psychiatry.org., 2018, What are anxiety disorders?, viewed 08 June 2018, from https://www.psychiatry.org/patients-families/anxiety-disorders/what-areanxiety-disorders.

Ramos, A., Pereira, E., Martins, G.C., Wehrmeister, T.D. \& Izidio, G.S., 2008, 'Integrating the open field, elevated plus maze and light/dark box to assess different types of emotional behaviors in one single trial', Behavioural Brain Research 193(2), 277-288. https://doi.org/10.1016/j.bbr.2008.06.007

Ravindran, L.N. \& Stein, M.B., 2010, 'The pharmacologic treatment of anxiety disorders: A review of progress', The Journal of Clinical Psychiatry 71(7), 839-854 https://doi.org/10.4088/JCP.10r06218blu

Rickels, K. \& Schweizer, E., 1997, 'The clinical presentation of generalized anxiety in primary-care settings: Practical concepts of classification and management', Journal of Clinical Psychiatry 58(11), 4-10.

Rodgers, R.J. \& Cole, J.C., 1994, 'The elevated plus-maze: Pharmacology, methodology and ethology', in S.J. Cooper \& C.A. Handrie (eds.), Ethology and psychopharmacology, pp. 45-60, John Wiley \& Sons, Baltimore, MD.

Rodgers, R.J., Cole, J.C., Cobain, M.R., Daly, P., Doran, P.J., Eells, J.R. et al., 1992, 'Anxiogeniclike effects of fluprazine and eltoprazine in the mouse elevated plus-maze: Profile
comparisons with 8-OH-DPAT, CGS 12066B, TFMPP and mCPP', Behavioural Pharmacology 3(6), 621-634. https://doi.org/10.1097/00008877-199212000-00009

Sadock, B.J. \& Sadock, V.A., 2003, Kaplan and Sadock's synopsis of psychiatrybehavioral sciences/clinical psychiatry, 9th edn., Lippincott Williams and Wilkins, Philadelphia, PA. (Chapter 16).

Schweizer, E. \& Rickels, K., 1997, 'Placebo response in generalized anxiety: Its effect on the outcome of clinical trials', The Journal of Clinical Psychiatry 58(Suppl. 11), 30-38.

Sheehan, D.V., Claycomb, J.B. \& Kouretas, N., 1980, 'Monoamine oxidase inhibitors: Prescription and patient management', The International Journal of Psychiatry in Medicine 10(2), 99-121. https://doi.org/10.2190/UVVY-HON2-B7V1-MHW0

Shelton, C.I., 2004, 'Diagnosis and management of anxiety disorders', The Journal of the American Osteopathic Association 104(3 Suppl. 3), S2-S5.

Stein, M.B. \& Stein, D.J., 2008, 'Social anxiety disorder', Lancet 371(9618), 1115-1125. https://doi.org/10.1016/S0140-6736(08)60488-2

Taura, D.W., Arzai, A.H. \& Oyeyi, T.I., 2009, 'Evaluation of antimicrobial activities of Combretum micranthum L. Bayero', Journal of Pure and Applied Sciences 2(1), 183-185. https://doi.org/10.4314/bajopas.v2i1.58540

Trullas, R. \& Skolnick, P., 1993, 'Differences in fear motivated behaviours among inbred mouse strains', Psychopharmacology, (Berl) 111(3), 323-331. https://doi. org/10.1007/BF02244948

Tshikalange, T.E., Meyer, J.J.M., Lall, N., Muñoz, E., Sancho, R., Van de Venter, M. et al., 2008, 'In vitro anti-HIV-1 properties of ethnobotanically selected South African plants used in the treatment of sexually transmitted diseases', Journal of Ethnopharmacology 119(3), 478-481. https://doi.org/10.1016/j.jep.2008.08.027

Udoh, I.P., Nworu, C.S., Eleazar, C.I., Onyemelukwe, F.N. \& Esimone, C.O., 2012 'Antibacterial profile of extracts of Combretum micranthum G. Don against resistant and sensitive nosocomial isolates', Journal of Applied Pharmaceutical Science 2(4), 142-146. https://doi.org/10.7324/JAPS.2012.2426

Vogel, G.H., 2002, Drug discovery and evaluation: Pharmacological assays, 2nd edn., Chapter H, pp. 702-770, Springer-Verlag, Berlin.

Vythilingam, M., Anderson, E.R., Goddard, A., Woods, S.W., Staib, L.H. \& Charney, D.S., 2000, 'Temporal lobe volume in panic disorder - A quantitative magnetic resonance imaging study', Psychiatry Research 99(2), 75-82. https://doi. org/10.1016/S0925-4927(00)00055-X

World Health Organization (WHO), 2005, National policy on traditional medicine and regulation of herbal medicines, Report of WHO global survey, WHO Press, Geneva.

Yapo, B.M., Besson, V., Beourou, S. \& Koffi, K., 2014, 'Optimization of water-extract of phenolic and antioxidant compounds from Kinkéliba (Combretum micranthum) leaves', African Journal of Food Science Research 2(1), 037-043.

Yonkers, K.A., Dyck, I.R., Warshaw, M. \& Keller, M.B., 2000, 'Factors predicting the clinical course of generalised anxiety disorder', British Journal of Psychiatry 176(6), 544-549. https://doi.org/10.1192/bjp.176.6.544 